ISSN 1991- 8690

website : http: //jsci.utq.edu.iq

الترقيم الدولي 8690 - 2091 - 2019

\title{
Relationship between hyperthyroidism and pulmonary function tests in female patients
}

\author{
Azza Sajid Jabbar Alkinany \\ Pharmacy College - Basra University. \\ E-mail: azzalkinany@yahoo.com
}

\section{$\underline{\text { Abstract }}$}

This is a comparative study carried out into two groups of females of age range 25-60years:20 healthy and 21 female patients with hyperthyroidism group, who were attending Alsadar teaching outpatient hospital, Basra City, Iraq. The aim of this study was to determine the effect of hyperthyroidism on the pulmonary function tests. Pulmonary function tests such as FEV1, FVC, FEV1\%, PEF and estimated lung age were all measured for all subjects involved in this study. The measurements were done by using a Spirolab III spirometer. It's found highly significant declines $(\mathrm{p}<0.01)$ in FEV1, FVC and FEV1\% in hyperthyroid female patients. While there was a significant decline in PEF at the level 0.05 of significance. The estimated lung age showed highly significant increase ( $\mathrm{p}<0.01$ ) of the hyperthyroid females compared to the healthy females. Hyperthyroid females showed deterioration in all studied lung function tests.

Key words: pulmonary function tests, hyperthyroidism.

$$
\begin{aligned}
& \text { العلاقة بين فرط نشاط الغدة الارقية واختبارات وظائف الرئة في الإناث المرضى } \\
& \text { عزه ساجد جبار الكناني } \\
& \text { كليه الصيدله- جامعه البصره }
\end{aligned}
$$

الخلاصة

نفذت هذه الدراسه على مجموعتين من الاناث ضمن المدى العمري 25-60 سنه ،مجموعه الاصحاء ومجموعه المرضى المصابين

بفرط نشاط الغده الدرقيه المرتادين العياده الخارجية لمستشفى الصدر التعليمي والتي تهدف الى تحديد تاثير فرط نشاط الغده الدرقية على وظائف الرئة .اختبارات وظائف الرئه FEV1,FVC,FEV1\%,PEF وعمر الرئه جميعها قد قيست للمرضى المشمولين بالدراسة .تم القياس

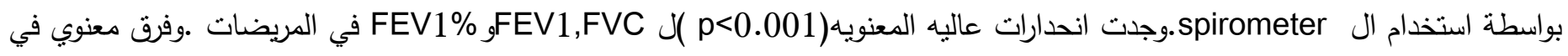
عند مستوى المعنويه 0.05.عمر الرئه التقديري اظهر زيادة معنوية عاليه في المريضات .(P>0.01). ان المريضات بفرط نشاط الغدة

$$
\text { الدرقية اظهرن تدهور في جميع وظائف الرئة المدروسة. }
$$

\section{Introduction}

Hyperthyroidism is a syndrome due to excessive amount of thyroid hormones in blood stream .This syndrome can significantly accelerate the metabolism .Typical symptoms of hyperthyroidism include sudden weight loss, a rapid heart rate ,sweating ,heat intolerance ,nervousness or irritability ${ }^{[1]}$ Causes of hyperthyroidism include over activity of the gland ,benign tumor carcinoma of the thyroid and Grave's disease (exopthalmic goiter ${ }^{[2] .}$ Thyroid gland by its anatomical location and its action can 
alter airflow dynamics and cellular metabolism at the macro and micro level in the disease condition $^{[3]}$ and thyroid hormones disorder impact respiratory system leading to respiratory disorder and even respiratory failure ${ }^{[4]}$. The pulmonary physical characteristics such as pulmonary volumes ,compliance and performance are evaluated by measuring of pulmonary function tests ${ }^{[5]}$. The aim of this study was to determine the effect of hyperthyroidism on the pulmonary function tests and possibility to involve the pulmonary function tests disorders within the symptoms of hyperthyroidism .

\section{Material and methods}

Two groups of females within the range (25-60 years)of age were studied:21 female patients with hyperthyroidism group, who were attending Alsadar teaching outpatient hospital ,Basra City,Iraq.They were already diagnosed as hyperthyroid patients depending on the findings of clinical examination and the results of thyroid function tests as major requirements for the diagnosis of disease. All patients have been on neomercazole as antithyroid drug in a dose of a range between $30-60 \mathrm{mg}$ according to the patient's requirement. Other group is 20 control subjects, who were apparently healthy. The source of this group was from the staff of the Medical College, Basra University and the patients 'relatives who accompanied the hyperthyroid patients. All subjects of the two groups were free of any respiratory diseases or any other condition which may alter pulmonary function tests obesity, pregnancy and smoking history.

Pulmonary function tests such as FEV1: Forced Expiratory Volume at the first second of Expiration, FVC: Forced Vital Capacity, FEV1\%: ratio of FEV1 to FVC, PEF: Peak Expiratory Flow and estimated lung age were all measured for all subjects involved in this study .Pulmonary function tests are used to evaluate broad range of lung disorders including airflow obstruction, restriction, exercise limitation and bronchial hyper-reactivity. Spirometry is an essential component in the medical evaluation of patients complaining of breath shortness and to monitor the effect of environmental and occupational exposure [6]. The measurements were done by using a spirometer, (the spirolab III MIR-Medical International Research USA ,Inc.).Spirolab III spirometer is the 3rd generation laboratory spirometer.

Measurement of pulmonary function tests for all patients was done at the same period of day before 12:00pm.Each individual had to repeat the measurement three times in order to take the best record, because the measurement procedure is highly subjected and depend on patient's cooperation.

\section{Statistical analysis}

Statistical analysis of the data was done using t-test, statistical package SPSS(Statistical Packages for Social Science ).Data expressed by mean $\pm \mathrm{SE}$ .The comparison between the studied groups was tested at the level of 0.05 of significance [7 ].

\section{Results}

When comparing between the two studied groups :hyperthyroid female patients $(\mathrm{n}=21)$ and healthy subjects $(\mathrm{n}=20)$ in pulmonary function tests ,it's found highly significant declines $(\mathrm{p}<0.01)$ in each of $\mathrm{FEV} 1(\mathrm{p}=0.0018), \mathrm{FVC}(\mathrm{p}=0.0064)$ and FEV1\%( $\mathrm{p}=0.0049)$. While there was a significant difference in PEF at the level 0.05 of significance. $(p=0.03)$.Table (1).Overall declines in pulmonary function may be reflected by the outcome lung parameter :the estimated lung age .The estimated lung age showed highly significant increase of the hyperthyroid females compared to the healthy females $(\mathrm{p}<0.01, \mathrm{p}=0.000195)$.

Table(2)showed the comparison between the real age and estimated lung age of both two studied groups ,expressed by $($ mean \pm SE).It's found a high significant difference between the real age and the estimated lung age of the hyperthyroid females group only, $(p<0.01, p=0.00042)$. While it's not a significant difference between these two parameters of the healthy females group, $(\mathrm{p}>0.05, \mathrm{p}=0.21)$. 
Table (1): Lung function tests comparison between healthy females and patient females

\begin{tabular}{|l|l|l|l|}
\hline \multicolumn{1}{|c|}{$\begin{array}{c}\text { Groups } \\
\text { Parameters }\end{array}$} & $\begin{array}{c}\text { Hyperthyroid female } \\
\text { patients } \\
(\text { mean+SE) }\end{array}$ & \multicolumn{1}{c|}{ Healthy subjects } & \multicolumn{1}{c|}{ P value } \\
\hline FEV1 & $2.74 \pm 0.36$ & $3.48 \pm 0.14$ & $0.0018^{* *}$ \\
\hline FVC & $3.31 \pm 0.22$ & $4.05 \pm 0.17$ & $0.0064^{* *}$ \\
\hline FEV1\% & $80.46 \pm 1.13$ & $84.32 \pm 0.84$ & $0.0049^{* *}$ \\
\hline PEF & $6.22 \pm 0.42$ & $7.29 \pm 0.34$ & $0.03^{*}$ \\
\hline Lung age & $82.95 \pm 9.88$ & $42.8 \pm 2.1$ & $0.000195^{* *}$ \\
\hline No. & 21 & 20 & \\
\hline
\end{tabular}

* Significant at the level 0.05, $(\mathrm{p}<0.05)$,

** Significant at the level 0.01, $(\mathrm{p}<0.01)$

Table(2):Comparison between estimated lung age and real age of the healthy and patients subjects.

\begin{tabular}{|c|c|c|l|}
\hline $\begin{array}{c}\text { Parameters } \\
\text { (Mean } \pm \text { SE })\end{array}$ & Real age & Estimated lung age & P value \\
\hline groups & $44.6 \pm 0.9$ & $42.8 \pm 2.1$ & 0.13 \\
\hline $\begin{array}{c}\text { Healthy subjects } \\
\text { female patients }\end{array}$ & $45.2 \pm 1.12$ & $82.95 \pm 9.88$ & $0.00042^{*}$ \\
\hline
\end{tabular}

${ }^{*}$ Highly significant, $\mathrm{p}<0.01$.

\section{Discussion}

Thyroid hormones play critical roles in the lung development, surfactant synthesis and even in lung defense [ ${ }^{8]}$ That is why this study was done. Many studies have reported that both hypothyroidism and hyperthyroidism significantly impact ventilatory control mechanisms ${ }^{[4,9] .}$ In case of hyperthyroidism, as this study delt with, it's found that thyroid hormones are associated with myopathy of inspiratory muscles as well as expiratory muscles ${ }^{[10]}$, leading to reduced smooth muscles contractility ,respiratory muscles weakness and then respiratory failure ${ }^{[11]}$ Muscles dysfunction may be caused by increased proteolysis with reduced expression of myocine heavy chain type I and type II in the diaphragm muscles biopsy ${ }^{[12]}$ Weakness of respiratory muscles may be related to the faster or shallower breathing pattern of the hyperthyroid patients in order to minimize the work necessary to achieve a given ventilation [13]. Moreover elevated thyroid hormones will reduce critical surfactant protein expression in human lung cells, which causes lack of adequate surfactant. This inadequate surfactant production results in reduced pulmonary compliance and reduced gas exchange ${ }^{[14]}$. All of these important findings in hyperthyroidism may explain clearly the significant changes in all pulmonary function tests studied: FEV1, FVC, FEV1\%and PEF, even if the patients have been on medication . The concept of estimated lung age has been recently used to follow up the patients with different respiratory diseases .It can be used 
especially to follow up the airflow decline over time ${ }^{[15]}$ Estimated lung age showed significant increases in the hyperthyroid females, referring certainly to deterioration in lung function tests in this specific disease.

Acknowledgments. This study was supported by instructions and advices of Dr.Ibrahim falih ,a general surgeon and a lecturer in the Medical College ,Basra University.

\section{References}

1-Jonathan, H .Li,Safford,Aduen J F,Heckman M G,Crook JE and Burger CD. Pulmonary hypertension and thyroid diseases .Chest; 2007,132:793-797.

2-Saaresranta ,T. and Polo, O. Hormones and breathing. Chest; 2002,122: 2165-2182.

3-Sugarpriya, G. Pulmonary function studies in hyperthyroid females with goiter -before and after thyroid surgery.Int Biol Med Res.; 2011,2(3):661-663.

4-Stockley, RA.and Bishop ,JM. Effect of thyrotoxicosis on the reflex hypoxic respiratory drive. Clin Sci Mol Med; 1977, 53: 93-100.

5-Kendrick, AH. O'Reilly JF. Laszlo G. Lung function and exercise performance in hyperthyroidism before and after treatment. Q J Med; 1988, 68: 615-627.

6-Wanger, J. Pulmonary function testing .A practical approach.Jones and Bartlett Learning, 2012, $3^{\text {rd }}$ ed.

7- SPSS Statistical Packages of Social Science. Version 15. USA.2006.

8-Wonters, E FM., Pollefliet, C., Testemans, D., Grinten CV. Pulmonary manifestations of endocrine and metabolic disorders .In: Verleden G.M., Demedts M.G., Westhovens R., and Thomeer. M. Pulmonary Manifestations of Systemic Diseases.
European Respiratory Society Monograph; 2006, 34: 234-252.

9-Engel ,LA. Ritchie, B. Ventilatory response to inhaled carbon dioxide in hyperthyroidism. $\mathbf{J}$ Appl Physiol; 1971, 30: 173-177.

10-Pino-Garcia, JM. Garcia-Rio ,F. Diez ,JJ, et al. Regulation of breathing in hyperthyroidism: relationship to hormonal and metabolic changes. Eur Respir J; 1998, 12: 400-407.

11-Mier ,A. Brophy, C. Wass JA. Besser, GM. Green, M. Reversible respiratory muscle weakness in hyperthyroidism. Am Rev Respir Dis; 1989, 139: 529-533.

12-Laghi, F. Tobin, MJ. Disorders of the respiratory muscles. Am J Respir Crit Care Med; 2003,168: 10-48.

13-Siafakas, NM. Milona, I. Salesiotou, V. Filaditaki, V. Tzanakis, N. Bouros, D. Respiratory muscle strength in hyperthyroidism before and after treatment. Am Rev Respir Dis; 1992, 146: 1025-1029.

14-Griesen, O. Pedersen upper airways obstruction in thyroid diseases; 2002,164(15):2033-2037.

15-Petty, $T$ L. A new national strategy for COPD.The Journal of Respiratory Disease.; 1997,18(4):365-368. 